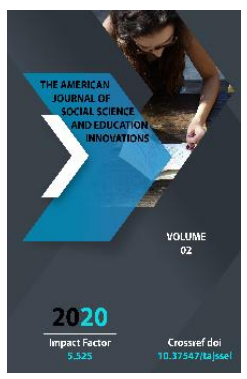

\title{
The Stage Of Turkism In Russian Language
}

\author{
Musadjanova Gulchekhra Abdumanapovna \\ Russian Teacher Of Joint Educational Program Of National University Of Uzbekistan Named \\ After Mirzo Ulugbek And Kazan Federal University, Uzbekistan
}

Journal Website: http://usajournalshub.c om/index,php/tajssei

Copyright: Original content from this work may be used under the terms of the creative commons attributes 4.0 licence.

\section{ABSTRACT}

In this article, we consider the borrowing and spreading of Turkism in Russian language. The authors focus on the reflection of the Turkisms in the Russian language. During the analysis, phonetic, morphological, lexical aspects of Turkism we revealed. The article focuses on the place of Turkism in Russian poetry. The authors come to the conclusion that the study of the Turkisms in Russian is necessary for a more objective understanding of the development and enrichment trends of a particular language.

\section{KEYWORDS}

Turkisms, lexemes, accentuation, onomastics, expressiveness, emotionality.

\section{INTRODUCTION}

The mutual influence Slavonic and Turkish was so long and intensive, that left deep marks in all spheres of these languages lexics in phraseology, in part of phonetics and grammar. 
Lexic devides into word in every language that means general conception of human and words with national ethnic cultural value.

Range to human's general meaning, at first, official part of speech, numerals, pronounces and some categories of adverb. The second, names and verbs, that means human's general conception, practically timeless and unspace ideas, for example: "young”, "old”, "good", "bad", “child”, "man”, "water”, “sky”, “to eat”, “to sleep”, “to go” and etc.

Research in complex at ethnic culture of Russian and Turkish nations, complete each other that allow determining genesis and the way of developing for the whole concepts and expressions. For 1000 years, Russian and Turkish in the period of ideate developed the similar or resembling social- political and economic circs, comprise to the same countries: Bulgaria, Golden horde, Kazah's khanate and Russian Empire. This circumstance determined intensive mutual influence.

Turkism takes part considerable place of Russian lexics. Turkism as a word immediately adopted from Turkism and Russian, from Turkism's origin.

Such wise, in order to state the real origin of words, definition of term "Turkism" divides all Turkism into 2 groups:

1. Primordial Turkism - are adopted words to Russian, which belong to original part of dictionary, for example: gold, roan, gloom and etc.

2. Historical Turkism are words, depending on Turkism, which haven't Turkism's origin and adopted from another languages. (Persian, Arabic, Mongolian) Turkism describes clear specific evidence of phonetics, semantic and morphology. In the Turkism's materials are followed various sonic process, lexicalsemantical scene, morphological changing, that absolutely presents considerable interests for researching Russian and other slovanic. The result of Turkism's complex studying for Russian especially, ethnic- culture lexics can serve invaluable source for recovering separate fragments of its history. Turkism imagines the special branch of loan. It is difficult to find that or the other historical epoch, whenever the mutual enrichment of East Slavic and Turkism is stopped.

A lot of Turkism came deep to conscience of Russian as "own" lexeme, finding a statue of language sign in the history and culture of Russian. For example: hero, sarafan, barge hauler, novel, knuckle. During the hundreds years, could stay in Russian as a barbarism, sending us to the east- culture, for instance basmach, argamak, shepherd, gaydamak, shaitan (demon), turban. Accent adoption of Turkism shows up the specificity, reflecting various stages of entrance to the Russian's system, also different stylistic character for detail use.

Turkism differs into criterions: 1 . Phonetic; 2. Accentuation; 3. Phonetic- accentuation; 4. Morphological; 5. Lexical- semantical (scene homonymy): kulak ("handgrip”) - kulak "niggard", "pleasant exploiter", kultuk "armpit”, kultuk "corner, puffin”, “ckreek". There are more than 30 words, which conformed from turkik's base. "Bash- bashlik "headwear" - bashlik " a leader", "a chieftain", bashlik "a horse bridle, a halter", bashka "a head" - bashka "to build above cellar" and etc. 
Turkism found own image in Russian surnames. N. A. Baskarov analyzed a lot of surnames, their lineage and history in this book "Russian surnames with Turkic origin" [M. Science 1979]. This work requests part of Russian families with Turkic origin.

Kurakins. This surname is from Turkic that means "wet" and "mean". There is synonym of this word in Uzbek, too. Such as: "wet plage, a mean man".

Turgenevs. This surname of Turkic means "turgun - speedy, brave". A great Russian writer belongs to this humanity. It means "stable" in Uzbek.

Ushakovs. The surname "Ushakovs" means "small, a short man" in Turkic. The word "ushoq" means "chit" for the first meaning, "a title" for figurative meaning.

Learning Turkism is one of the paramount tasks of modern linguistics. Turk were one of the perceptible facts in the national languages interaction. Typicals for Russian romanticists, used peculiar properties of Turkism, distinctively said by A. Bastujev's creation, which was directly familiar with the life of Turkic nation. A. Bastujev had gone the way of progressively increasing esthetic role of Turkism, in his ballade "Soatir" (1828) written in siperian link, before "Ammalat - hostess", "Mulla- nura" and etc. period of Caucasian 1 composition. In 30-th years, Turkisms permeated not only his compositions, his articles, his letters, too.

There are many of Turkisms in their poetic speech, which belongs to the different sphere of social- political mode of life.

Poetry by M. B. Lomonosov, A. P. Sumarokov, M. M. Heraskov and G. R. Derjavin played the unpriced role in assimilation Turkic lexics in Russian literature.

It is characteristically used Turkic onomasticon for Russian literature "Tamir and Selim" are heroes taken from five- act tragedy: Mumet is a king of Crimea, Mamay is a king of Tatarian, Tamira is a queen, Mumetov's daughter, Selim is a king of Bagdad, Narsim is a king of Crimea, Nadir is Mumetov's brother. Sumarokov's satires are abounded Turkism's too: diamond, money, a chest tobacco, a boob, taffeta, goldcloth, a golden- box and the others. In Satire epigram "A boob is always boob, who was before". In Turkism "balvan" helps to create a negative value. In ancient Russian language Turkism "balvan" mean "Idol”, which connected with historical present. Turkism "balvan" includes to a semantical perceiving system of Russian, and this word has a figurative meaning "stupid", which is fixed in the explanatory dictionaries.

In compositions by M. M. Heraskov "in Russia", "Golden rob", which is dedicated to conquering above Kazan's khanate, a king Ivan the terrible and Russian Turkic war is used a big number of Turkism; alcoran, magamet, boyars, hordes, diamond, carpets, mohammedanism, beads, books, tatarian. The poem is abounding Turkic onomasticons: Aley, Safgurey, Sumbeka, Yediger, Batiy, Sartak, Bapkay, Mengu, Temir, Uzbek, Mamay, Tohtamish, Sapgun, Yemre.

There are ranges of Turkic onomasticons in the lyrics of Anna Ahmatova. A poetess reminded the name of Tamerlan for several times. (Tamerlan the Great, Amir Temur, Temur, Temur the Great) - a Turkic chieftain, who played the notable role in the Asian's and Uzbekistan's history. In the poem, which is dedicated to "Bons Pasternak", the spring is comparing with wasting nine of Amir Temur. 
"Spring fells Temirlan again, abbey alleys keep silence" [Ahmatova 1989; 291]. In the 19-th century, Russian poet A. I. Polejaev wrote an epithef of Temirlanovs. In his message to A. P. Lazovskiy G. R. Derjavin reminded about Tamerlan about in his "odes Felicia" "Taking Ismail" (1791); "It is nice to be a great tyrant as Tamerlan”, “Ovveride Tamirovs” [Derjavin, 1957; 10316]. The name of a chieftain Tamerlan is very successfully rethought by poetess. The nature is revitalizing, Autumnis enbowing with human internals, antonomaziya is happening, which is having a big psychological impact to society and people. Poets and poetess and need its help, using fijne- impressively arsenals for receiving own conciliator, which shown in the composition of A. Ahmatova, where the beginning of spring is compared with wasty invasion of Tamerlan. A poetess used the name of Chingizhan in the poem "An inscription on the portret", she means "Chingizhan" "People went out of him, he was sent for". [Ahmatova 1989, 254].

There are widely used lots of old and new turkics in the poem of A. A. Ahmatova, many of them are used as labeled words. A quantity of examples from A. A. Ahmatova's poetry is an evidence for turkism's metaoric system of Russian literature. In the poem "Tashkent's pages", the metaoric word "month" is compared with "diamond felucca", threemasted ship with three- masted- Canvas.

But diamond folucca month swam under "the meet separation". In the poem "when the moon lyin" the metaoric is formed similarity to the moon's colour and a slice of melon. "When the moon is lyin as a chardjuy melon in the corner of window, smells around". A. A. Ahmatova had to pay of Turkic family, taken as a pen- name, that requested human's courage. "Don't dominate a street and stave by Ahmatova", "Tatarin, dense comes from nowhere, she is trouble" [Ahmatova, 1989; 250]. There are two lexics- semantic groups, which include marine, common, social lexics, names of fish, birds, plants, valuable stones, musical instruments, shoes, clothes, materials in her poems. Turkism took part as art pictoride resources, giving special soleness to her poems.

An art- onomastic of Turkism executes the function of formation spatial coordinate exotic East, which the role was always important and seminal in Russian literature tradition in the lyric cycle of S. A. Esenin "Persian motives". Onomasticon of "Persian motives" sends a reader to toponyms that means actually existing reals. "Tegeran with blue. I treat them in the teahouse now" [Esenin, 1999; 276]. "Xarasan has so doors, where the flowers are stew on the doorsteps". [Esenin, 1999; 285] the capital name, the title of the provinces in the NorthEast Iran is performing the main article tasktransfers a reader to unknown world, magic, which has absolutely another culture. It is also important that a poet consciously poetically gives spatial coordinates of Iran, Persian and his poetical cycles, meaning the real, being out if Iran, the another side to Turkish, ("lighter wind, quitter Van's plume”) [Esenin, 1999; 278]. "I have never been to Basfor, don't ask me about [...] Although, I have not been in Basfor, I think up it for you" [Esenin, 1999; 279] The another is Irak (I didn't go to Bagdad with procession, I didn't carry silk and henna there" [Esenin, 1999; 279] Nevertheless, the particularity reference at real coordinate is stated distinctly "I think up it for you", "Persian motives" include so turkisms as veil, teahouse, teahouseman, a dog, dirk, shawl, fog, silk, Persian, charm, saffaron, Magomet, coran and etc.) Turkisms enriched the Russian literature with new units, with new reality, most of part passed to nationwide colloquial, 
refined its expressive, emotion and imagery. Research Turkisms in Russian is necessary not only for deep understanding to develop nation's culture, it is necessary to objective understanding of tendency developing and to enrich this or another concrete language.

\section{REFERENCES}

1. R. A. Yunaleeva. Turkisms of Russian language. (field aspect problem researching) Kazan, Taglimat, 2000$72 \mathrm{p}$.

2. A. E. Kojevnikova. Turkisms in modern Russian language.

3. Baskakov N. A. Turkish language $-M$ : Restored publishing literature, 1960242p.

4. Baskakov N. A. Russian surnames with Turkic origin. M: Science, 1979-248p.

5. Shipova E. H. turkisms dictionary in Russian language. Alma- Ata; Science, 1976- 444p.

6. G. H. Tilazetdinova, T. G. Fomina. Turkism"s accentual adaptation in Russian language. Philology and Culture. 2012 №2 (28)

7. Xeraskov M. M. "In Russia” Epic//. M. M. Xeraskov selected works. M. L.: Soviet writer, 1961.

8. The role of Turkism in the poesy. A. Ahmatova / kultur Evreni uc ayda bir yayimlanam Uluslararasi sosial bilimler dergisi bahar. Turkiye, 2009, №2, p 179- 186.

9. Sumarokov A. P. Poems L., Soviet writer 1961, p 15

10. Derjavin G. R. (1957) Poems. L., Soviet writer.

11. Ahmatova A. A. Lyric, M., Art literature, 1989, p282

12. Esenin S. Poems. L; Soviet writer. 1999, p276- 285 